\title{
Falciparum malaria associated acute kidney injury with polyneuropathy and intra-arterial thrombosis (stroke)
}

\author{
Nausheen Butt ${ }^{*}$ (10 and Ejaz Ahmed
}

\begin{abstract}
Background: Malaria is still major problem in developing countries, such as Pakistan. Besides fever, body ache and vomiting it can present with acute kidney injury, proteinuria, hematuria and cerebral manifestations which are more common with falciparum malaria. Neurological manifestations are rare presentation of malaria and should be consider in patients who are admitting with features of neuropathy and stroke.

Case presentation: We describe an unusual case of falciparum malaria, complicated by acute kidney injury who developed Polyneuropathy and intra-arterial thrombosis in middle cerebral artery territory. Our patient recovered his renal functions during admission and recovered his power and sensation in his limbs as well after 1 month.

Conclusion: Malaria cause neurological manifestations including axonal and sensory neuropathy, cerebral venous and arterial thrombosis, PMNS, cerebellar signs and symptoms, psychosis, etc. With prompt diagnosis and early treatment they can be cure and regain their motor and sensory functions to normal level.
\end{abstract}

Keywords: Malaria, Acute kidney injury, Polyneuropathy, Intra-arterial thrombus

\section{Background}

In 2019, there were an estimated 229 million cases of malaria worldwide with estimated number of deaths stood at 409,000 [1]. A total of 374,513 confirmed malaria cases have been reported from all the public sector health facilities across Pakistan in annual report of 2019, among which 6.5 million malaria suspects were screened at these health facilities [2]. Falciparum malaria affected $18 \%$ patients who diagnosed with malaria in Pakistan according to last surveillance study conducted in 2011 [3]. Besides common presentations there are some uncommon manifestations of falciparum malaria, such as hemiplegia, cranial nerve palsies, myelitis-like syndrome, psychosis, cerebellar ataxia and peripheral neuropathy etc. [4]. We describe an unusual presentation of

*Correspondence: dr.nousheen@yahoo.com

Sindh Institute of Urology and Transplant, Karachi, Sindh, Pakistan falciparum malaria with polyneuropathy (both motor and sensory) plus intra-arterial thrombus (causing stroke) in a single young male patient along with acute kidney injury.

\section{History}

An 18-year-old male, resident Sindh, Pakistan, farmer by profession, previously no known co morbids, admitted in Sindh institute of urology and transplantation emergency due to complaints of high grade fever with chills, intermittent, from last 8-9 days, relieve temporarily on taking medicines prescribed by general practitioner nearby, but he was not getting better and developed left flank pain, after 4 days he became drowsy and developed loss of consciousness. No history of seizures, vomiting, loose stools, sore throat, and cough, shortness of breath, hematuria or cola colored urine. He developed decrease urine output for 1 day. original author(s) and the source, provide a link to the Creative Commons licence, and indicate if changes were made. The images or other third party material in this article are included in the article's Creative Commons licence, unless indicated otherwise in a credit line to the material. If material is not included in the article's Creative Commons licence and your intended use is not permitted by statutory regulation or exceeds the permitted use, you will need to obtain permission directly from the copyright holder. To view a copy of this licence, visit http://creativecommons.org/licenses/by/4.0/. The Creative Commons Public Domain Dedication waiver (http://creativeco mmons.org/publicdomain/zero/1.0/) applies to the data made available in this article, unless otherwise stated in a credit line to the data. 


\section{Antecedents}

He got admitted in Nawabshah hospital, where Foleys catheter was passed, $500 \mathrm{ml}$ urine came out in bag, NG (Nasogastric tube) passed and IV line maintained. Given IV fluids. CT scan brain done there which was normal. His routine labs done there showed Hemoglobin (Hb); 8.1 g/dl (normal range 10-12 g/dl), Total Leukocyte Count (TLC): 10.0109/1 (normal range 4.0-11.0109/1), Platelets (PLT) 130,000,109/1 (normal range 150-400,109/1), Urea $91 \mathrm{mg} / \mathrm{dl}$ (normal range $10-40 \mathrm{mg} / \mathrm{dl}$ ), and Creatinine $3.5 \mathrm{mg} / \mathrm{dl}$ (normal range $0.6-1.5 \mathrm{mg} / \mathrm{dl}$ ). Serum Electrolytes were normal. Liver function tests (LFT's) were normal, Hepatitis surface antigen ( $\mathrm{HBsAg}$ ) and Hepatitis C antibodies (Anti HCV) were negative. Next day his Urea and Creatinine rise to $160 \mathrm{mg} / \mathrm{dl}$ and $4.5 \mathrm{mg} / \mathrm{dl}$, respectively, although his urine output was adequate. He was referred to Sindh Institute of Urology and Transplant (SIUT) hospital Karachi.

\section{Clinical examination}

Here in Emergency, his Glasgow Coma Scale [18] (GCS) was 4/15, Vitals: Pulse $122 \mathrm{~b} / \mathrm{min}$, Temperature: $102 \mathrm{~F}$, Respiratory rate 22/min, Blood Pressure: 122/85 mmHg, Pallor + ve, No jaundice, clubbing, edema, no lymphadenopathy. Clinically dehydrated. On examination he had flaccid paralysis of all four limbs (quadriplegia), not moving any limb on painful stimuli. No signs of meningeal syndrome. Reflexes were diminished in all limbs. Planter were equivocal. Rest of systemic examination were unremarkable. No hepatosplenomegaly.

\section{Biology, imaging and functional examination Basic work up showed}

Random Blood Sugar (RBS): 182 mg/dl, Oxygen Saturation at room air 93\%. Arterial Blood gases (ABG's): $\mathrm{pH}$ 7.4, $\mathrm{PCO}_{2}$ 33.0, $\mathrm{PO}_{2} 95$ and $\mathrm{HCO}_{3} 24$. Hematology Hb: $6.2 \mathrm{~g} / \mathrm{L}$, TLC $14 \times 10^{9} \mathrm{~L}$, platelets $73 \times 10^{9} \mathrm{~L}$. Prothrombin time (PT) 13.5, INR: 1.28 BIOCHEMISTRY : Urea $261 \mathrm{mg} / \mathrm{dl}$, Creatinine $3.5 \mathrm{mg} / \mathrm{dl}$, Sodium (Na): $177 \mathrm{mmol} / \mathrm{l}$ (normal range $135-145 \mathrm{mmol} / \mathrm{l}$ ), Potassium (K) $4.5 \mathrm{mmol} / \mathrm{l}$ (normal range $3.5-5.0 \mathrm{mmol} / \mathrm{l}$ ), Chloride $(\mathrm{Cl}) 140 \mathrm{mmol} / \mathrm{l}$ (normal range $100-106 \mathrm{mmol} / \mathrm{l}$ ), and Bicarbonate $\left(\mathrm{HCO}_{3}\right) 29 \mathrm{mmol} / \mathrm{l}$ (normal range 24-30 mmol/l). Calcium (Ca) $6.4 \mathrm{mg} / \mathrm{dl}$ (normal range 8.5-10.5 mg/dl), Albumin $2.44 \mathrm{~g} / \mathrm{dl}$ (normal range
3.5-5.0), and Phosphorus $\left(\mathrm{PO}_{4}\right): 3.65 \mathrm{mg} / \mathrm{dl}$ (normal range $2.7-4.5 \mathrm{mg} / \mathrm{dl}$ ), Liver function tests (LFT's) were normal except gamma GT 137 IU/l (normal 9-50 IU/l), alkaline phosphatase $275 \mathrm{IU} / \mathrm{l}$ (normal up to $104 \mathrm{IU} / \mathrm{l}$ ). Serum Lactate dehydrogenase (LDH): 1194 IU/l (normal 45-90 IU/l). Urine output was $900 \mathrm{ml}$ in urinary bag. Malarial parasite (MP) thick and thin films showed positive with plasmodium falciparum. Urine detail report (Urine DR) showed active urine sediments, i.e., RBC/s Numerous, Protein +3 .

He was tested negative for COVID-19 PCR (nasal swab sample).

Lumbar puncture (LP) was performed and Cerebral Spinal Fluid (CSF) sent for analysis which showed Glucose 117, Protein 97, LDH 80 and TLC count of 20 with $45 \%$ Neutrophils and 55\% lymphocytes. Culture negative came out later after 2 days. Urinary chemistry Sodium Na: $33 \mathrm{mmol} / \mathrm{l}$, K $35 \mathrm{mmol} / \mathrm{l}$, and Cl $31 \mathrm{mmol} / \mathrm{l}$. Fractional excretion of sodium was $1 \%$. He was having free water excretion with good urine output of around 2 1/day.

Spot Urine Protein $286 \mathrm{mg} / \mathrm{dl}$, urine creatinine $52 \mathrm{mg} / \mathrm{dl}, \mathrm{P} / \mathrm{C}$ ration of $5.5 \mathrm{~g}$. Complete Serology was ordered including $\mathrm{C} 3, \mathrm{C} 4$, ANA profile, serum IgA, IgG, IgM, ANCA titer and ASO titer. Antiphospholipid antibodies (APLA) serology and thrombophilia profile (factor v, protein $\mathrm{C}, \mathrm{S}$ and anti-thrombin 3 ) were also sent.

\section{Clinical and biological evaluation}

Neurologist was consulted who ordered MRI Brain and EMG/NCS After 3 days his urea and creatinine were $135 \mathrm{mg} / \mathrm{l}$ and $1.51 \mathrm{mg} / \mathrm{dl}$, respectively, $\mathrm{Na}: 164 \mathrm{mmol} / \mathrm{l}$, K: $3.4 \mathrm{mmol} / \mathrm{l}, \mathrm{Cl}: 133 \mathrm{mmol} / \mathrm{l}$ and $\mathrm{HCO}_{3} 22 \mathrm{mmol} / \mathrm{l}$. Therefore, he was having free water excretion which was corrected by giving free water from NG. After 2 days, he became conscious, awake alert with GCS of $15 / 15^{*}$

\section{MRI and MRA findings}

Small acute bilateral parietal infarcts and thrombosed intracerebral carotid artery. Pan sinusitis with bilateral mastoiditis. Arrows in these pics suggesting the ischemic areas and sites of thrombosis in vessels. 

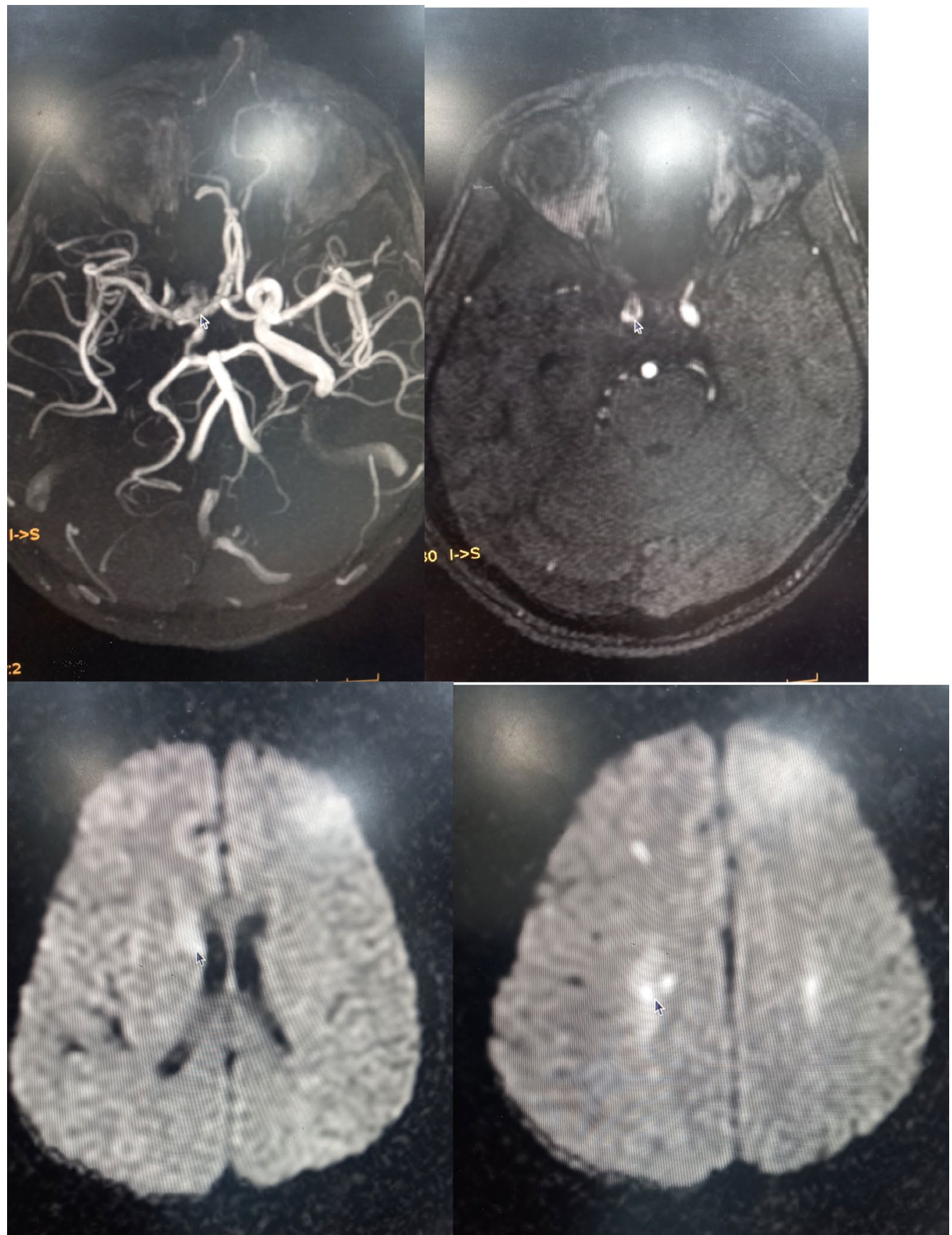

\section{EMG/NCS}

Bilateral median $(\mathrm{APB})$, post tibial $(\mathrm{AH})$ and right ulnar (ADQ) motor nerves conduction study normal. Bilateral Peroneal (EDB) and left ulnar (ADQ) motor nerves conduction studies showed low amplitude and nonrecordable $\mathrm{F}$ wave latencies. Bilateral $\mathrm{H}$ reflex studies were normal. Bilateral median F2 Ulnar F5 and Radial sensory nerves conduction studies were normal. Bilateral Sural sensory nerve conduction studies were non recordable. So that showed sensory motor axonal polyneuropathy more in lower limbs.

\section{Diagnosis}

Severe malaria with gravitational signs, pre renal form of acute renal failure, intracellular dehydration, sensory-motor polyneuropathy, cerebral artery thrombus. 


\section{Treatment and hemodialysis}

He was initially started on Intravenous fluid, started on broad spectrum antibiotics and had one session of Hemodialysis of $2 \mathrm{~h}$ duration, without ultrafiltration and without heparin. He was started on anti-malarial IV Artesunate $120 \mathrm{mg}$ four doses $12 \mathrm{~h}$ apart then IV OD for 5 days more then shifted to Tab. Artemether/Lumefantrine $(40 \mathrm{mg} / 240 \mathrm{mg}$ ) PO BD for 2 days. He was given IVF $1 / 2$ strength saline 118 hourly plus symptomatic management. Next day (after 1 session of Hemodialysis) his urea $145 \mathrm{mg} / \mathrm{dl}$, Creatinine $2.56 \mathrm{mg} / \mathrm{dl}$, Calcium $7.57 \mathrm{mg} / \mathrm{dl}$, Albumin $3.1 \mathrm{~g} / \mathrm{dl}$, Na: $160 \mathrm{mEq} / \mathrm{l}$, $\mathrm{K}: 3.8 \mathrm{mEq} / \mathrm{l}, \mathrm{Cl} 125 \mathrm{mEq} / \mathrm{l}, \mathrm{HCO}_{3} 27 \mathrm{mEq} / \mathrm{l}$, Phosphorus: $7.25 \mathrm{mg} / \mathrm{dl}$. After making final diagnosis $\mathrm{He}$ was given antiepileptic prophylactically Levetiracetam $250 \mathrm{mg}$ BD, vitamin B6 and vitamin B12, for thrombosis we started inj. Clexane $60 \mathrm{mg}$ (ENOXAPARIN SODIUM) Subcutaneous (SC) OD. After further 4 days his urea and creatinine became normal $46 \mathrm{mg} / \mathrm{dl}$ and $0.49 \mathrm{mg} / \mathrm{dl}$, respectively, and $\mathrm{Na}$ became $148 \mathrm{mmol} / \mathrm{l}$. He started moving his right arm, power improved in upper limbs but not in lower limbs. Inj. Clexane continued for 2 weeks more. His Na became $140 \mathrm{mmol} / \mathrm{l}$ after further 4-5 days and Urine output became normal and free water excretion decreased. His power improved gradually in all four limbs. He started walking with support. On discharge Power in upper limbs were $5 / 5$ and lower limbs 4/5 in Right and 3/5 in left lower limb proximally and 4/5 distally with intact reflexes and sensation. Autoimmune serology was negative C3, C4, ANA, Anti Ds DNA). Later his thrombophilia profile (Protein $\mathrm{C}$, S, anti-thrombin 3 and factor $\mathrm{V}$ mutan, homocysteine levels) came normal and APLA (anti phospholipid antibodies) negative. In addition, after 1 month on follow-up in OPD he had normal power in all four limbs.

\section{Discussion and conclusion}

Classical presentation of falciparum malaria is seen in $50-70 \%$ of the cases with the rest having atypical manifestations.

\section{Malaria and kidney}

Glomerunephritis is fairly common in falciparum malaria with albuminuria is seen in $20-50 \%$ of cases and acute diffuse malarial nephritis is rare with hypertension, albuminuria and edema. We also see Nephrotic syndrome as immune complex mediated nephropathy develops weeks after the malaria, it may be progressive and may require treatment with steroids or immunosuppressant [5]. More recent studies have also found IgA deposits in malaria [29, 30], Eosinophilic glomerulonephritis [31]. Autoantibodies have also been detected in patients with malariaassociated glomerulonephritis, but its role has yet to be determined [32]. Hemolytic-uremic syndrome (HUS) is also described in malaria [33]. In malaria-endemic regions, acute kidney injury (AKI) can occur in up to $40 \%$ of adult patients and it is associated $75 \%$ mortality when renal replacement therapy (RRT) is not started in time [6]. Microcirculation disorders, anoxia and subsequent necrosis of the glomeruli and renal tubules are responsible for this serious complication. ATN occurs in $1-4 \%$ of cases of $P$. falciparum infection. Disseminated intravascular coagulation also may cause or aggravate this problem. Histologic findings of malaria pigment in distal convoluted tubules are consistent with the reports of intravascular hemolysis and increased cell-free hemoglobin and heme in malaria-associated AKI $[27,28]$.

\section{Neuropathy during malaria: literature and diagnostic steps}

In literature various neuropsychiatric manifestations of falciparum malaria in different case reports and case series [7-19] have been described which are classified mainly into three groups [14]: (1) Sequelae of cerebral malaria, e.g., hemiplegia, cranial nerve palsies, neuropsychiatric signs and symptoms, such as psychosis, (2) Neuropsychiatric symptoms during acute stage as a presenting illness. (3) Neurological or psychiatric sign occurring with a latency of several days to weeks (generally within 2 months) after an episode of successfully treated P. falciparum malaria [12]. Most of the times, these neurological manifestations disappear after successful treatment of malaria itself with residual symptoms which disappear over the course of time with symptomatic management. Among various neuropsychiatric manifestations/sequelae of malaria GBS, such as polyneuropathy [17], acute and delayed cerebellar ataxia [24], acute inflammatory demyelinating polyneuropathy AIDP [16] autonomic neuropathy [15], bilateral axonal polyneuropathy [18] are reported mainly from Indian subcontinent. Exact cause of polyneuropathy is not known but has been attributed to immune mediated capillary damage, toxic oxygen radicals, tumor necrosis factor, parasitic emboli obstructing the vasa nervorum, neurotoxin release, nutritional and metabolic disturbances [16]. Most of PMNS characteristics can fit into the diagnosis of postinfectious encephalitis, ADEM (acute diffuse encephalomyelitis) or AIE (autoimmune encephalitis). Literature review of previous case reports showed that MRI is best modality to diagnose cerebral manifestations and CT failed to reveal any acute abnormalities. MRI abnormalities consisted of increased signal uptake in various regions, including the periventricular areas, pons, thalamus, corona radiata, internal capsule, and cerebellum. CSF analysis was performed in those cases, revealing a lymphocytic pleocytosis (>5 lymphocytes, range 10-76) in $50 \%$ and elevated protein in $69 \%$ of cases [19]. Our patient had 
same features, normal CT scan with positive findings in MRI and lymphocytic predominance in CSF with high protein. Cerebral malaria may be associated with raised intracranial pressure due to cerebral edema.

\section{Arterial thrombus during malaria-framework of an infectious vasculitis}

Infections including several viruses, fungi, bacteria, and parasites are associated with stroke. In patients with infective endocarditis, septic cerebral embolism is a significant risk factor for embolic strokes. Evidence also suggests that systemic infection may trigger acute stroke in patients with vascular risk factors.

Falciparum malaria infection influences blood coagulation by various interacting path biological mechanisms, the most important being the overwhelming response of the host to sepsis resulting in a cytokine storm. In addition, the parasite infects the red cells leading to changes in the red cell phospholipid composition which supports blood coagulation. Monocyte-macrophage system also gets activated in this infection compounding the hypercoagulable state. Heavy parasitemia leading to occlusion of hepatic microcirculation leads to abnormalities in synthesis and secretion of coagulation factors and their inhibitors. A hypercoagulable state resulting from severe malaria may be responsible for this rare and potentially fatal complication. Previous studies showed that ADAMTS13-activity was found to be reduced in malaria, indicating that a decrease in this enzyme probably occurs at later stages of malaria [21] and decreased blood platelet counts and elevated levels of vWF at very early stages of malaria infection [22]. One study showed that the thrombin generation potential might have a role in advanced infections and the development of complications during a $P$. falciparum infection [23]. Cerebral venous sinus thrombosis has been reported in previous case reports to be associated with severe malaria [20,35]. There is case report showing pulmonary embolism associated with falciparum malaria too [34]. Malaria with stroke was reported in 1999 with lesion in the region of the middle cerebral artery without any associated encephalitis [36]. Later in 2008 a case report of vertebrobasilar stroke with falciparum malaria was published as well presenting predominantly with signs of lateral medullary and cerebellar infarctions [37].

Intra-arterial thrombosis which is very rare presentation especially at this young age without any risk factors, such as Hypertension, Diabetes, dyslipidemia, smoking and medical history, and we excluded COVID-19 in this patient as well. The development of neurological manifestation after diagnosing malaria and improvement after starting antimalarial therapy strongly suggest that the ischemic stroke was mainly due to falciparum malaria.
There was no atherogenetic changes in carotid arteries as suggested by normal carotid Doppler and normal fundoscopy. Our case is unique in the way that stroke have never reported with polyneuropathy in a single patient yet. Although autonomic neuropathy and axonal neuropathy were reported in various case reports in past separately but our case has both sensory and axonal motor neuropathy in one patient. Plus our patient's neurological manifestations became better gradually with full recovery within 1 month after treatment. Our patient didn't receive steroids.

\section{Acknowledgements \\ Thanks to Dr. Adib ul Hassan Rizvi for his support regarding publishing my manuscript in this journal and believing in me. Dr. Fazal Akhtar: Professor of Nephrology and Dr. Sadia: Consultant Neurologist, SIUT for managing this patient and helped in diagnosis. Dr. Ameet Jersani: Radiology Department, SIUT for providing me relevant MRI images of patient.}

\section{Authors' contributions}

NB: 1st Author and corresponding author as well. Did Literature search and written this case report. EA: Did assig me this case, helped me in writing the case report.

\section{Funding}

None.

Availability of data and materials

Contact corresponding author for detailed reports and data.

\section{Declarations}

Ethics approval and consent to participate

This case report was approved by Research Committee Department of Sindh Institute of Urology.

\section{Consent for publication}

The patient was aware and gave consent for publication of his case in journal and Transplant under Dr. Naqi Zafar who approved this case report.

\section{Competing interests}

The authors declare that they have no competing interests.

Received: 14 October 2021 Accepted: 27 December 2021

Published online: 06 January 2022

\section{References}

1. World Malaria Report 2020. Published in WHO news feeds 30th Nov 2020.

2. Pakistan Malaria annual report 2019. Directorate of Malaria control. Islamabad.

3. Khattak AA, et al. Prevalence and distribution of human Plasmodium infection in Pakistan. Malar J. 2013;12:297.

4. Idro R, Jenkins NE, Newton CR. Pathogenesis, clinical features, and neurological outcome of cerebral malaria. Lancet Neurol. 2005;4:827-40.

5. da Silva Junior GB, Pinto JR, Barros EJG, Farias GMN, De Francesco Daher E. Kidney involvement in malaria: an update. Rev Inst Med Trop São Paulo. 2017;59:e53.

6. Koopsman LC, van Wolfswinkel ME, Hesselink DA, Hoorn EJ, et al. Acute kidney injury in imported Plasmodium falciparum malaria. Malar J. 2015;14:523.

7. Van der Wal G, Verhagen WI, Dofferhoff AS. Neurological complications following Plasmodium falciparum infection. Neth J Med. 2005;63(5):180-3. 
8. Falchook GS, Malone CM, Upton S, Shandera WX. Postmalaria neurological syndrome after treatment of Plasmodium falciparum malaria in the United States. Clin Infect Dis. 2003;37(2):e22-4.

9. ZambitoMarsala S, Ferracci F, Cecotti L, et al. Post malaria neurological syndrome: clinical and laboratory findings in one patient. Neurol Sci. 2006;27(6):442-4.

10. Lawn SD, Flanagan $\mathrm{KL}$, Wright SG, et al. Postmalaria neurological syndrome: two cases from the Gambia. Clin Infect Dis. 2003;36(2):e29-31.

11. Matias G, Canas N, Antunes I, Vale J. Post-malaria neurologic syndrome. Acta Med Port. 2008;21(4):387.

12. Nguyen $T H$, Day NP, Ly VC, Waller D, Nguyen HP, Bethell DB, Tran TH, White NJ. Post-malaria neurological syndrome. Lancet. 1996;348:917-21.

13. Kochar DK, Shubhakaran, Kumawat BL, Kochar SK, Halwai M, Makkas RK, et al. Cerebral malaria in Indian adults: a prospective study of 441 patients from Bikaner, northwest India. J Assoc Physicians India. 2002;50:234-41.

14. Kochar DK, Shubhakaran, Kumawat BL. Neuropsychiatric manifestations in malaria. J Assoc Physicians India. 1998;46:886-90.

15. Shubhakaran, Choudhary R. Polyneuropathy with autonomic involvement in Plasmodium falciparum malaria. J Vector Borne Dis. 2012:49:268-9.

16. Shubhakaran, Sharma CM. Acute inflammatory demyelinating polyneuropathy with P. falciparum malaria. J Assoc Physicians India. 2003;51:223-4.

17. Sokrab Tag-Eldin O, Eltahir A, Idris Mohammed NA, Hamid M. GuillainBarre syndrome following acute falciparum malaria. Neurology. 2002;59:1281-3.

18. Gupta N, Singh N, Mali S. Bilateral peroneal axonal neuropathy: a rare postmalarial neurological syndrome. J Case Rep. 2013;3(2):433-5.

19. Markley JD, Edmond MB. Post-malaria neurological syndrome: a case report and review of the literature. J Travel Med. 2009;16(6):424-30.

20. Krishnan A, Karnad DR, Limaye U, Siddharth W. Cerebral venous and dural sinus thrombosis in severe falciparum malaria. J Infect. 2004;48:86-90.

21. de Mast Q, Groot E, Asih PB, Syafruddin D, Oosting M, Sebastian S, et al. ADAMTS13 deficiency with elevated levels of ultra-large and active von Willebrand factor in P. falciparum and P. vivax malaria. Am J Trop Med Hyg. 2009;80:492-8.

22. de Mast Q, Groot E, Lenting PJ, de Groot PG, McCall M, Sauerwein RW, et al. Thrombocytopenia and release of activated von Willebrand Factor during early Plasmodium falciparum malaria. J Infect Dis. 2007;196:622-8. https://doi.org/10.1086/519844.

23. Riedl J, Mordmüller B, Koder S, et al. Alterations of blood coagulation in controlled human malaria infection. Malar J. 2016;15:15. https://doi.org/ 10.1186/s12936-015-1079-3.

24. Dey AB, Trikha I, Banerjee M, Jain R, Nagarkar KM. Acute disseminated encephalomyelitis - another cause of post malaria cerebellar ataxia. J Assoc Physicians India. 2001;49:756-8.

25. Teasdale G, Jennett B. Assessment of coma and impaired consciousness: a practical scale. Lancet. 1974;304:81-4.

26. Tamzali Y, et al. Post-malaria neurological syndrome: four cases, review of the literature and clarification of the nosological framework. Malar J. 2018;17:387. https://doi.org/10.1186/s12936-018-2542-8.

27. Elphinstone RE, Conroy AL, Hawkes M, Hermann L, Namasopo S, Warren HS, John CC, Liles WC, Kain KC. Alterations in systemic extracellular heme and hemopexin are associated with adverse clinical outcomes in Ugandan children with severe malaria. J Infect Dis. 2016;214(8):1268-75.

28. Plewes K, Kingston HWF, Ghose A, Maude RJ, Herdman MT, Leopold SJ, Ishioka H, Hasan MMU, Haider MS, Alam S, et al. Cell-free hemoglobin mediated oxidative stress is associated with acute kidney injury and renal replacement therapy in severe falciparum malaria: an observational study. BMC Infect Dis. 2017;17(1):313.

29. Yoo DE, Kim JH, Kie JH, Park Y, Chang TI, Oh HJ, et al. Immunoglobulin A nephropathy associated with Plasmodium falciparum malaria. J Korean Med Sci. 2012;27:446-9.

30. Rafieian-Kopaei M, Nasri H, Alizadeh F, Ataei B, Baradaran A. Immunoglobulin A nephropathy and malaria falciparum infection; a rare association. Iran J Public Health. 2013:42:529-33.

31. Walker A, Ellis J, Irama M, Senkungu J, Nansera D, Axton J, et al. Eosinophilic glomerulonephritis in children in Southwestern Uganda. Kidney Int. 2007;71:569-73.

32. Eisenhut M. Auto-antibodies and glomerulonephritis in Plasmodium falciparum malaria. Autoimmunity. 2010;43:640-1.
33. Kute VB, Trivedi HL, Vanikar AV, Shah PR, Gumber MR, Kanodia KV. Collapsing glomerulopathy and hemolytic uremic syndrome associated with falciparum malaria: completely reversible acute kidney injury. J Parasit Dis. 2013;37:286-90.

34. Musoke C, Ssendikadiwa C, Babua C, Schwartz Jl. Severe falciparum malaria associated with massive pulmonary embolism. Ann Afr Med. 2014;13:47-9

35. Luvira V, Chamnanchanunt S, Thanachartwet V, et al. Cerebral venous sinus thrombosis in severe malaria. Southeast Asian J Trop Med Public Health. 2009;40(5):893-7.

36. Leopoldino JF, Fukujima MM, Gabbai AA. Malaria and stroke: case report. Arq Neuropsiquiatr. 1999;57:1024-6.

37. Kaushik RM, Kaushik R, Varma A, et al. Plasmodium falciparum malaria presenting with vertebrobasilar stroke. Int J Infect Dis. 2009;13(5):e292-4.

\section{Publisher's Note}

Springer Nature remains neutral with regard to jurisdictional claims in published maps and institutional affiliations.
Ready to submit your research? Choose BMC and benefit from:

- fast, convenient online submission

- thorough peer review by experienced researchers in your field

- rapid publication on acceptance

- support for research data, including large and complex data types

- gold Open Access which fosters wider collaboration and increased citations

- maximum visibility for your research: over $100 \mathrm{M}$ website views per year

At BMC, research is always in progress.

Learn more biomedcentral.com/submissions 